\title{
THE EFFECTS OF PRUNING TYPE ON WIND LOADING OF ACER RUBRUM
}

\section{E. Thomas Smiley and Brian Kane}

\begin{abstract}
The wind load, bending moment, height, and weight were determined for 81 red maples (Acer rubrum) before and after pruning. Trees were thinned, reduced, lion tailed, or stripped of foliage. All three pruning treatments reduced wind load significantly compared to unpruned trees at all tested velocities $(11,16$, and $20 \mathrm{~m} / \mathrm{sec}$ [ 25,35 , and $45 \mathrm{mph}]$ ). Reduction in wind load increased with increasing velocity. Differences in wind-load reduction between reduction pruning and thinning were not significant at any velocity. The reduction in wind load was linearly related to the amount of weight removed by pruning treatments. Compared to the same trees prior to pruning, the center of pressure height was significantly lowered on thinned and reduced trees, while the center of pressure height did not change on lion-tailed trees.

Key Words. Biomechanics; tree failure; tree pruning; wind resistance; windthrow.
\end{abstract}

While a substantial body of literature exists on the critical wind speeds to cause windthrow or stem breakage for commercially important coniferous timber species (e.g., Picea abies, $P$. sitchensis, P. radiata, and P. sylvestris), including effects of silvicultural treatments, stocking levels, and soil types (Cremer et al. 1982; Gardiner and Quine 2000), much less research has been conducted on wind loading of shade trees. Niklas and Spatz (2000) included a large, decurrent Prunus serotina in an examination of the uniform stress hypothesis. Others have investigated shade trees with regard to dynamic loading and natural frequencies (Baker and Bell 1992; Roodbaracky et al. 1994; Baker 1997).

Pruning shade trees to reduce the risk of failure has been a tool that arborists and urban foresters have used since the early 20th century. Early arborists' observations and intuition led to creating a smaller or more permeable canopy that they believed would reduce wind load and the risk of failure. One early pruning practice that intended to accomplish this was topping. With this type of pruning, the upper portions of branches were severed at a point on the branch where it was easy to cut or at a consistent height, usually an internode. Another type of pruning that began as a misapplication of thinning was lion tailing. With lion tailing, the lower foliage and branches on leaders and scaffold branches were removed, leaving a cluster of twigs and leaves on the distal portion of branches. Aesthetic concerns notwithstanding, both lion tailing and topping have adverse physiological consequences for trees and are no longer recommended pruning practices (ANSI 2001; Lilly 2001; Gilman and Lilly 2002).

Topping a healthy tree results either in a profusion of watersprouts near the cut or death of the remaining portion of the branch (Lilly 2001). Topping also facilitates the spread of decay from the point of the cut down into the branch (Shigo 1986). Lion tailing reduces a tree's photosynthetic capability, especially on hot summer days: stomata of exterior foliage close and only the cooler interior foliage retains photosynthesis potential (Shigo 1986). Lion tailing also increases the potential for sunscald on thin-barked trees (Lilly 2001).

The American National Standard Institute A300 pruning standard (ANSI 2001) recommends two pruning types, thinning and reduction, that, in theory, would reduce wind load on the tree while not having the negative aesthetic or physiological impact on the tree. Thinning is the selective removal of branches throughout the canopy to reduce canopy density. ANSI A300, \$5.6.2, recommends removal of not more than $25 \%$ of live foliage during an annual growing season (ANSI 2001). Reduction, according to \$5.6.4, is selective removal of branches to decrease canopy height and/or spread (ANSI 2001).

With forest trees, branch removal from the side and top of the canopy provides the best protection against failure (Moore and Maguire 2001; Rowan et al. 2003), although many trees die as a result of such pruning. In a computer simulation, Hedden et al. (1995) showed that removal of $25 \%$ to $50 \%$ of canopy weight was the most effective way to reduce tree loss from windthrow or stem breakage under hurricane-force winds. It has been suggested that crown reduction is a better way than crown thinning to reduce the risk of shade tree failure because it reduces both the height and area of the canopy (Ball 2003). However, there do not appear to be any investigations of how pruning types affect wind loading of shade trees.

The objective for this research was to determine the effect of different pruning types on wind loading of small shade trees.

\section{MATERIALS AND METHODS}

Red maples (Acer rubrum) grown in a field under nursery conditions at the Bartlett Tree Research Laboratory in Charlotte, North Carolina, U.S., with $3.7 \times 4.6$ m (12.2 × $15.2 \mathrm{ft}$ ) offset spacing were used for testing. Testing was 
conducted between 9 September 2003 and 1 October 2003, while trees were in leaf.

A $14 \mathrm{~mm}$ (9/16 inch) diameter hole was drilled through the trunk 10 to $15 \mathrm{~cm}$ (4 to $6 \mathrm{in}$ ) above the soil line. Trees were then cut 5 to $10 \mathrm{~cm}$ ( 2 to $4 \mathrm{in}$ ) above the soil line to avoid the root flare. Diameter at $15 \mathrm{~cm}$ (6 in) above the hole was measured, and pre- and post-pruning measurements of canopy height, total tree height, canopy spread, and tree weight were taken.

Trees were fastened to a custom-made steel frame mounted in the bed of a pickup truck with a $12 \mathrm{~mm}(1 / 2$ inch) diameter bolt (Figure 1). They were then hoisted into a vertical position and fastened to a Dillon model ED-2000 plus electronic dynamometer (Dillon, Fairmont, MN) using a $0.6 \mathrm{~cm}$ (1/4 inch) diameter extra-high-strength cable and a $2.5 \mathrm{~cm}$ (1 in) wide sling attached $76 \mathrm{~cm}$ (30.4 in) above the hole. The dynamometer cable remained parallel to the truck bed throughout the tests.

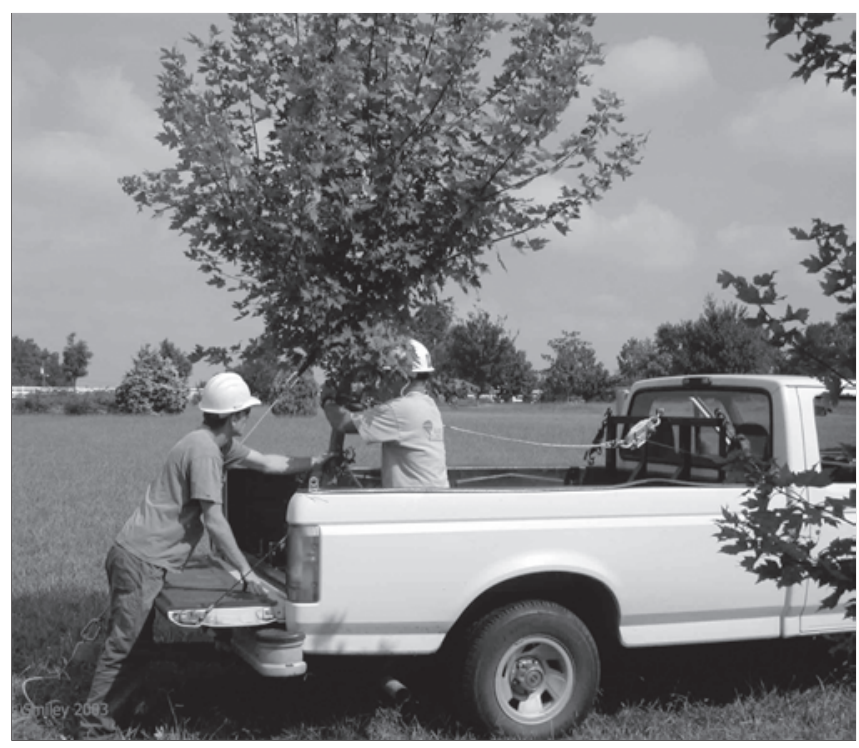

Figure 1. Truck setup used for testing wind loading.

The truck and tree were driven with constant acceleration up to $20 \mathrm{~m} / \mathrm{sec}(45 \mathrm{mph})$. Force measurements were recorded at 11, 16, and $20 \mathrm{~m} / \mathrm{sec}(25,35$, and $45 \mathrm{mph})$. Before placing trees in the truck, an anemometer was placed where the tree would be, and wind speeds were checked against the speedometer. Above the cab height, anemometer readings did not vary more than $1.5 \mathrm{~m} / \mathrm{sec}(3 \mathrm{mph})$. To compensate for ambient wind, two force measurements were recorded for each tree at each speed. This was accomplished by making two passes with the truck in directly opposite directions. The force values used for subsequent calculations of wind load were the average of these two runs. Typically, all testing was completed within 30 min of cutting down the tree, before there was visual evidence of foliar wilting.
After taking two force measurements with the canopy intact, the tree was pruned according to one of four types (listed below). Thinning and reduction were accomplished in the manner described in the ANSI A300 pruning standard (\$5.6.2, §5.6.4) and ISA's Best Management Practices: Tree Pruning (ANSI 2001; Gilman and Lilly 2002) for mature shade trees. To simulate field conditions, the percentage of foliage removed (described below) was based on visual estimation by an ISA Certified Arborist. For the first three trees, which were treated according to pruning types 1 through 3 (listed below), three Certified Arborists visually compared the amount of foliage and twigs removed to ensure that it represented the intended amount of foliage and twigs to be removed for the particular pruning type. The same Certified Arborist pruned all trees to maintain consistency in the amount and location of foliage and twigs removed for each pruning type.

Pre- and post-pruning measurements of tree weight tracked the amount of foliage and twigs removed. Because wind resistance is related to canopy weight (Mayhead 1973; Mayhead et al. 1975; Rudnicki et al. 2004; Vollsinger et al. 2005), we compared how effectively pruning treatments reduced wind load relative to the weight of foliage and twigs removed. This was important for two reasons. First, trees varied in size; therefore, removing a certain percentage of foliage and twigs did not remove the same amount of weight for each tree. Second, the pruning types did not necessarily remove the same amount of foliage and twigs. Treatments were as follows:

1. Thinning. Approximately $25 \%$ of the foliage was removed from the tree by removing small branches, 3 to 12 $\mathrm{mm}$ (1/8 to $1 / 2$ in) diameter, throughout the canopy. Tree height and canopy width were not changed during thinning. This treatment was applied to 26 trees.

2. Reduction. Tree canopy height and width were reduced $25 \%$ by removing twigs from the perimeter of the canopy, primarily using reduction cuts. Typically, the sides of the tree were reduced $30 \mathrm{~cm}$ (12 in) and the top $60 \mathrm{~cm}$ (2 $\mathrm{ft}$ ), although this varied due to differences in canopy dimensions. This treatment was applied to 25 trees.

3. Lion tailing. Foliage and small branches were removed from the bottom half of the canopy. Lion tailing was accomplished by twig pruning and hand removal of leaves attached to lower scaffold branches. Canopy height and width were not changed nor were scaffold or other branches greater than $1 \mathrm{~cm}$ (0.4 in) diameter removed. This treatment was applied to 23 trees.

4. Leaf stripping. All leaves were manually removed from the tree by hand stripping each branch. Twigs and branches were left intact. This treatment was applied to six trees.

A digital image was taken of each tree before and after pruning. The images were analyzed using Adobe Photoshop 
and ImageJ software (Wayne Rasband, Research Services Branch, National Institute of Mental Health, Bethesda, MD) to determine the height of the center of pressure of the canopy. This is the distance from the buttress to the centroid of the frontal area of the tree. It is based on a still air image of the tree and will change to some degree as branches deflect and leaves reconfigure in the wind (Mayhead 1973). The centroid of any area is the point at which a disk of uniform thickness and constant density would balance and lay flat. The sum of infinitesimal wind loads on the entire canopy can be assumed to act at the center of pressure (Beer and Johnston 1988). Force measurements were multiplied by the ratio of dynamometer height to center of pressure height from the original ground level to convert force measurements into calculated wind load values. From pre- and post-pruning images of each canopy, the difference in center of pressure height was calculated.

Bending moments were calculated by multiplying the calculated wind loads (the bending force) by the center of pressure height (the lever arm over which the bending force acts). To determine risk of tree failure, bending moment, not wind load alone, was used to calculate mechanical stress in the trunk.

It is important to recognize that different amounts of foliage and twigs were removed for each pruning type. The objective was not to remove the same amount of foliage and twigs but rather to prune trees as an arborist would in the field. Although different amounts of foliage and twigs were removed, this is what would happen in practice because the A300 specifies in \$5.6.2 and \$5.6.4 the type and location of foliage and twigs to prune, not the amount (ANSI 2001). To account for varying amounts of foliage and twigs removed by different pruning types, we analyzed the wind-load reduction per unit of weight removed (i.e., amount of foliage and twigs pruned). In addition, examining reductions in both wind load and bending moment elucidated the influence of pruning type on the center of pressure height as well as the amount of foliage and twigs removed. This is important because bending moment, not wind load alone, determines the mechanical stress a tree endures.

Statistical analysis was conducted using the SAS system, version 8 (SAS Institute Inc., Cary, NC). Pre- and postpruning comparisons of tree weight, center of pressure height, wind load, and bending moment were analyzed as matched pairs (unpruned and pruned) of trees using the analysis of variance and Tukey's Studentized Range test to separate means. Pairing pruned and unpruned data was necessary to correct for variation in tree size. Mean differences among treatments refer to differences in reduction of wind load and bending moment from unpruned trees, not absolute values of wind load for each treatment. Regression analyses were also performed to investigate relationships between wind load and velocity and between reduction in wind load and the weight of foliage and twigs removed by pruning. Trees that were stripped of foliage were not included in the statistical analysis because of the small sample size.

\section{RESULTS AND DISCUSSION}

The mean tree diameter measured $15 \mathrm{~cm}$ (6 in) above grade was $7.54 \mathrm{~cm}$ ( 3 in). Mean tree weight was $16.1 \mathrm{~kg}$ (35.4 lb). Lion tailing removed an average of $3.32 \mathrm{~kg}(7.3 \mathrm{lb}, 19 \%)$ of foliage and twigs per tree. This was significantly $(P=0.03)$ greater than reduction pruning or thinning, which removed an average of $2.43 \mathrm{~kg}(5.3 \mathrm{lb}, 13 \%)$ and $1.93 \mathrm{~kg}(4.2 \mathrm{lb}$, $11 \%)$ of foliage and twigs, respectively. The intent of thinning and reduction pruning was to remove approximately equal leaf surface areas, but there was weak evidence to suggest that reduction pruning removed more biomass $(P=0.12)$. Although visually estimating how much foliage to remove represents the situation arborists face in the field, inherent variation in this method is shown by the coefficient of variation $(\mathrm{CV})$ for the percentage of tree weight removed within a given pruning type (lion tailing $\mathrm{CV}=23 \%$, reduction $\mathrm{CV}=36 \%$, thinning $\mathrm{CV}=25 \%$ ). Considering this variation, combined with the complexity of measuring wind load on trees (Vogel 1994), higher P-values (less evidence to attribute differences to treatment rather than error) are presented throughout this section. This has been done to present potentially informative data for future investigations, as suggested by Marini (1999).

All three pruning treatments reduced wind load significantly $(P<0.01)$ compared to unpruned trees at all tested velocities (Table 1). Reduction in wind load increased with increasing velocity, presumably due to the curvilinear relationship between wind load and velocity. For unpruned trees, wind load was proportional to velocity raised to an exponent of 1.4 (Figure 2). This is less than the relationship between wind load and a rigid body, where wind load is proportional to velocity squared, but greater than what has been found for some conifers, where wind load was proportional to velocity (Fraser 1962; Mayhead et al. 1975).

Differences among pruning types in the reduction in wind load were contingent on velocity (Table 2). At $11 \mathrm{~m} / \mathrm{sec}$ (25 mph), there were no significant differences among any of the pruning types. As velocity increased, differences became evident (Table 2). This finding is probably due to the ability of tree canopies to reconfigure in the wind, which presents a smaller area upon which the wind acts. At some threshold velocity, reconfiguration is no longer effective and leaves begin to tear or break off (Vogel 1989). This finding would explain why pruning types start to show different abilities to reduce wind load only at higher wind velocities. It is not surprising that lion tailing reduced wind load more than reduction or thinning because it removed more weight - and wind load is related to tree weight (Mayhead et al. 1975; Rudnicki et al. 2004; Vollsinger et al. 2005). 
Table 1. Mean reduction in wind load at three velocity levels $(11,16$, and $20 \mathrm{~m} / \mathrm{sec}[25,35$, and $45 \mathrm{mph}])$ for each pruning type or for trees with all of the foliage stripped off of the branches.

\begin{tabular}{|c|c|c|c|c|}
\hline Pruning type & $\begin{array}{l}\text { Velocity } \\
\text { (m/sec) }\end{array}$ & $\begin{array}{l}\text { Velocity } \\
\text { (mph) }\end{array}$ & $\begin{array}{l}\text { Reduction in } \\
\text { wind } \operatorname{load}^{z}(\mathrm{~N})\end{array}$ & $P$-value \\
\hline Lion tailed & 11 & 25 & 78 & $<0.01 *$ \\
\hline Lion tailed & 16 & 35 & 140 & $<0.01 *$ \\
\hline Lion tailed & 20 & 45 & 200 & $<0.01 *$ \\
\hline Reduced & 11 & 25 & 96 & $<0.01 *$ \\
\hline Reduced & 16 & 35 & 130 & $<0.01 *$ \\
\hline Reduced & 20 & 45 & 144 & $<0.01 *$ \\
\hline Stripped & 11 & 25 & 136 & $<0.01 *$ \\
\hline Stripped & 16 & 35 & 209 & $<0.01 *$ \\
\hline Stripped & 20 & 45 & 270 & $<0.01 *$ \\
\hline Thinned & 11 & 25 & 45 & $<0.01 *$ \\
\hline Thinned & 16 & 35 & 78 & $<0.01 *$ \\
\hline Thinned & 20 & 45 & 103 & $<0.01 *$ \\
\hline
\end{tabular}

${ }^{2}$ Reduction in wind load (measured in newtons, $\mathrm{N}$ ) is the difference between wind load before pruning and wind load after pruning. *Highly significant difference in wind load before and after pruning or stripping foliage.

Differences in wind-load reduction between reduction pruning and thinning were not significant at any velocity.

The reduction in wind load was linearly related to the amount of weight removed by pruning treatments (Figure 3), consistent with earlier findings on conifers (Fraser 1962; Mayhead et al. 1975). However, this relationship was significant only at $20 \mathrm{~m} / \mathrm{sec}(45 \mathrm{mph}$ ). Figure 3 also illustrates the significant $(P=0.05)$ difference between the slopes of regression lines for reduction pruning and thinning. There is a greater reduction in wind load per unit of biomass removed with reduction pruning than with thinning. This difference increases as more weight is

\section{Table 2. Mean difference in wind-load reduction between specified pruning} types.

\begin{tabular}{lllcc}
\hline $\begin{array}{l}\text { Velocity } \\
(\mathrm{m} / \mathrm{sec})\end{array}$ & $\begin{array}{l}\text { Velocity } \\
(\mathrm{mph})\end{array}$ & Pruning comparison & $\begin{array}{l}\text { Mean wind load } \\
\text { reduction difference (N) }\end{array}$ & \begin{tabular}{c} 
P-value \\
\hline 11
\end{tabular} \\
25 & Lion tailed vs. reduced & -18 & 0.99 \\
16 & 35 & Lion tailed vs. reduced & 10 & 1.00 \\
20 & 45 & Lion tailed vs. reduced & 56 & 0.06 \\
11 & 25 & Lion tailed vs. thinned & 32 & 0.73 \\
16 & 35 & Lion tailed vs. thinned & 62 & $0.02^{*}$ \\
20 & 45 & Lion tailed vs. thinned & 97 & $0.01^{*}$ \\
11 & 25 & Reduced vs. thinned & 51 & 0.11 \\
16 & 35 & Reduced vs. thinned & 52 & 0.09 \\
20 & 45 & Reduced vs. thinned & 41 & 0.37 \\
\hline
\end{tabular}

${ }^{z}$ Mean difference was calculated by subtracting the wind load reduction of the second pruning type listed in the pruning comparison column from the wind load reduction of the first pruning type. Negative differences indicate that the first listed pruning type did not reduce wind load as much as the second listed pruning type. Reduction in wind load is the difference between wind load before pruning and wind load after pruning.

*Highly significant difference between pruning types.

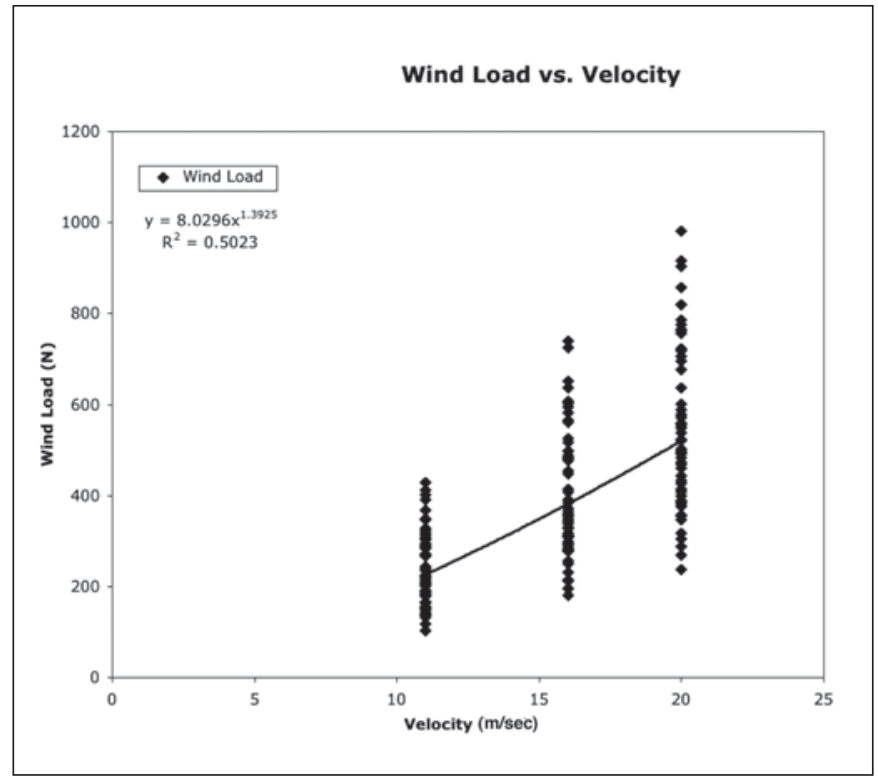

Figure 2. Scatter plot and best fit line for the relationship between wind load on unpruned trees and velocity.

removed because reduction pruning lowers the center of pressure height more than thinning does. A similar relationship between line slopes for reduction pruning and lion tailing exists, although the evidence is not strong $(P=0.12)$ and reflects the fact that lion tailing removed more weight than reduction pruning did. This comparison is important because comparing the effectiveness of how pruning treatments reduce wind load must consider how much weight was removed by each pruning treatment.

Compared with the same trees prior to pruning, the center of pressure height was significantly lowered on the trees reduced by thinning and reduction pruning (12 and 17 $\mathrm{cm}[30$ and $43 \mathrm{in}$ ], respectively, $P<$ $0.01)$. Change in the center of pressure height on lion-tailed trees was not significant ( $1 \mathrm{~cm}$ [0.4 in], $P=0.48)$. Because the reduction pruning lowered tree height on average by 60 $\mathrm{cm}(2 \mathrm{ft})$, it is not unexpected that the center of wind-load pressure was significantly lower $(P=0.02)$ than that on the thinned trees.

Lion tailing did not reduce bending moment more than reduction pruning or thinning did at any velocity (Table 3), which can be attributed to the fact that it did not reduce the center of pressure height. This is an important result because, although it shows that even though lion tailing removed more twigs and foliage, which consequently 


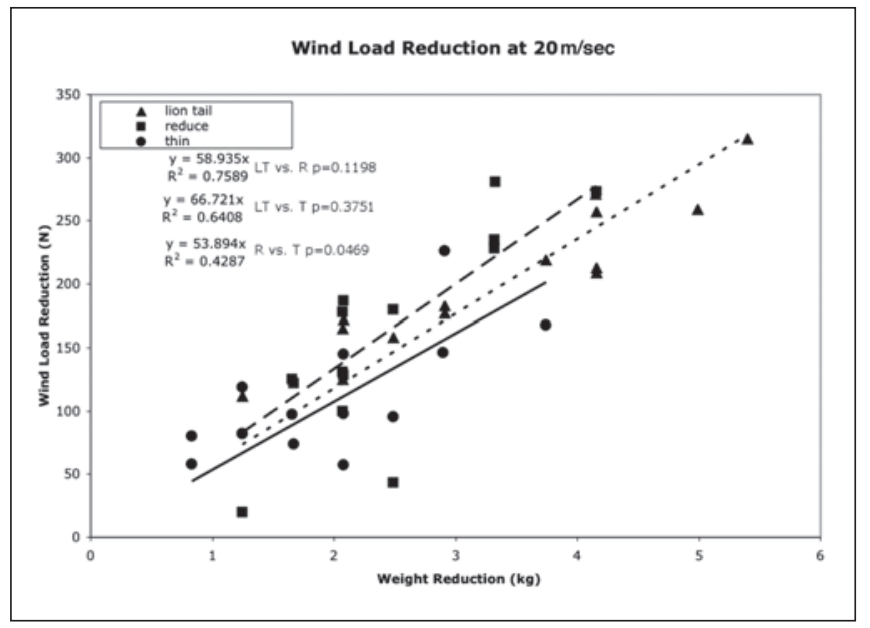

Figure 3. Scatter plot and best fit lines for the relationship between reduction in wind load at $20 \mathrm{~m} / \mathrm{sec}$ (45 mph) and reduction in weight (unpruned tree weight minus pruned tree weight) for three pruning types. $P$ values relate to the comparison of line slopes for pruning types listed.

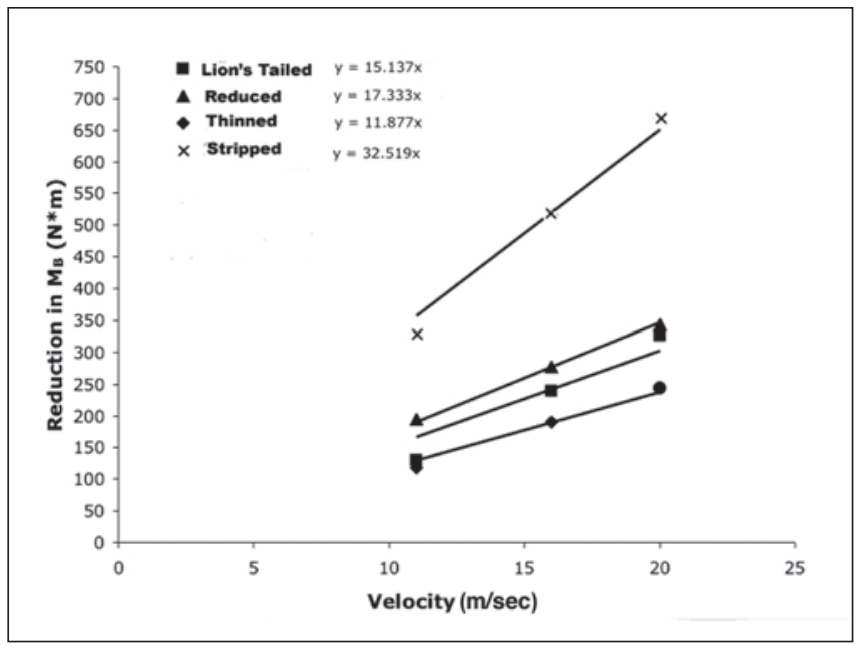

Figure 4. Mean reduction in bending moment $\left(M_{B}\right)$ at three velocity levels $(11,16$, and $20 \mathrm{~m} / \sec (25,35$, and $45 \mathrm{mph}]$ ) for each of three pruning types and with all of the foliage stripped off. reduced wind load more than reduction pruning did (at $20 \mathrm{~m} / \mathrm{sec}[45$ mph]) and thinning (at 16 and $20 \mathrm{~m} / \mathrm{sec}$ [35 and $45 \mathrm{mph}$ ), it would not be the preferred pruning type to reduce tree risk. At 11 and 16 m/sec [15 and 35 $\mathrm{mph}]$, there were no significant differences between bending moments of thinned and reduction pruned trees.

Some evidence exists that reduction pruning reduced bending moment more than thinning did at $20 \mathrm{~m} / \mathrm{sec}$ (45 mph), presumably due to the lower center of pressure height (Table 3, Figure 4). At lower velocities, thinned trees may have reconfigured their canopies enough to compensate for the imposed lower center of pressure height in reduction-pruned trees. Especially for smaller trees, which can deflect under wind load more than larger trees (King 1986, Niklas and Spatz 2000), stem deflection is important in reducing wind load and bending moment (Cannell and Coutts 1988). Larger trees may not benefit as much from a lower center of pressure height due to stem deflection (King and Loucks 1978; Bertram 1989) because trunks become increasingly stiff (King 1986) and only the smaller, more elastic branches will deflect. The results from this study should not be extrapolated to larger trees or higher wind speeds without further testing. pruning types.
Table 3. Mean difference in bending moment reduction between specified

\begin{tabular}{lllcc}
\hline $\begin{array}{l}\text { Velocity } \\
(\mathrm{m} / \mathrm{sec})\end{array}$ & $\begin{array}{l}\text { Velocity } \\
(\mathrm{mph})\end{array}$ & Pruning comparison ${ }^{z}$ & $\begin{array}{l}\text { Mean bending } \\
\text { moment difference (N*m) }\end{array}$ & \begin{tabular}{l} 
P-value \\
\hline 11
\end{tabular} \\
25 & Lion tailed vs. reduced & -66 & 0.77 \\
16 & 35 & Lion tailed vs. reduced & -39 & 0.99 \\
20 & 45 & Lion tailed vs. reduced & -18 & 1.00 \\
11 & 25 & Lion tailed vs. thinned & 11 & 1.00 \\
16 & 35 & Lion tailed vs. thinned & 48 & 0.96 \\
20 & 45 & Lion tailed vs. thinned & 90 & 0.29 \\
11 & 25 & Reduced vs. thinned & 77 & 0.51 \\
16 & 35 & Reduced vs. thinned & 87 & 0.31 \\
20 & 45 & Reduced vs. thinned & 108 & 0.07 \\
\hline
\end{tabular}

${ }^{z}$ Mean difference was calculated by subtracting the bending moment reduction (before-pruning bending moment minus after-pruning bending moment) of the second pruning type listed in the pruning comparison column from the bending moment reduction of the first pruning type. Negative differences indicate that the first listed pruning type did not reduce bending moment as much as the second listed pruning type.

\section{CONCLUSIONS}

All three pruning treatments reduced wind load significantly compared to unpruned trees at all tested velocities $(11,16$, and $20 \mathrm{~m} / \mathrm{sec}[25,35$, and $45 \mathrm{mph}])$. The differences in wind-load reduction between reduction pruning and thinning were not significant at any velocity. The reduction in wind load was linearly related to the amount of weight removed by pruning treatments. Considering the increased probability of branch decay that results from severe reduction pruning (Gilman 1997) and the increased risk of 
branch failure when decay is present (Matheny and Clark 1994), further investigations must be conducted to determine whether reduction pruning is more effective at reducing the risk of tree failure than thinning. Additional studies are under way that incorporate larger trees and higher wind velocities. These studies are necessary in light of Mayhead (1973), who noted that trees shorter than $3.5 \mathrm{~m}$ (11.6 ft) were morphologically different from larger trees, and this difference affects how much trees bend under wind load. A study modeling failure of loblolly pine (Pinus taeda) did not detect differences among treatments to reduce tree mortality until wind velocity exceeded $40 \mathrm{~m} / \mathrm{sec}(89.5 \mathrm{mph})$ (Hedden et al. 1995). The current study nevertheless provides a baseline for much-needed data on this important aspect of arboriculture and urban forestry.

Compared with the same trees prior to pruning, the center of pressure height was significantly lowered on thinned and reduced trees, while the center of pressure height did not change on lion-tailed trees. Lion tailing has been discredited as a viable pruning technique because of its adverse physiological consequences and tendency to reduce branch taper over time (Lilly 2001; Gilman and Lilly 2002). Poor taper has been suggested as a likely cause of stem failure from wind (Cremer et al. 1982; Putz et al. 1983; Petty and Swain 1985) and snow loading (Petty and Worrell 1981). This study makes the point that for the amount of foliage removed, lion tailing is not a good method of reducing the effects of wind.

\section{LITERATURE CITED}

American National Standards Institute. 2001. American National Standard for Tree Care Operations-Tree, Shrub, and Other Woody Plant Maintenance-Standard Practices (Pruning) (A300, Part 1). Tree Care Industry Association, Manchester, NH. 9 pp.

Baker, C.J. 1997. Measurements of the natural frequencies of trees. Journal of Experimental Botany 48(310):1125-1132.

Baker, C.J., and H.J. Bell. 1992. The aerodynamics of urban trees. Journal of Wind Engineering and Industrial Aerodynamics 41-44(1992):2655-2666.

Ball, J. 2003. Topics in Plant Health Care: The role of pruning. Arborist News 12(2):13-14.

Beer, F.P., and E.R. Johnston. 1988. Vector Mechanics for Engineers: Static (5th ed.). McGraw-Hill, New York, NY. $472 \mathrm{pp}$.

Bertram, J.E.A. 1989. Size-dependent differential scaling in branches: The mechanical design of trees revisited. Trees 4:241-253.

Cannell, M., and M. Coutts. 1988. Growing in the wind. New Scientist 21:42-46.
Cremer, K.W., C.J. Borough, P.H. McKinnel, and P.R. Carter. 1982. Effects of stocking and thinning on wind damage in plantations. New Zealand Journal of Forest Science 12(2):244-265.

Fraser, A.I. 1962. Wind tunnel studies of the forces acting on the crowns of small trees. Report on Forest Research. HMSO, London, UK. pp. 178-183.

Gardiner, B.A., and C.P. Quine. 2000. Management of forests to reduce the risk of abiotic damage-A review with particular reference to the effects of strong winds. Forest Ecology and Management 135:261-277.

Gilman, E.F. 1997. An Illustrated Guide to Pruning. Delmar, New York, NY. 178 pp.

Gilman, E.F., and S.J. Lilly. 2002. Best Management Practices: Tree Pruning. International Society of Arboriculture. Champaign, IL. 35 pp.

Hedden, R.L., T.S. Fredericksen, and S.A. Williams. 1995. Modeling the effect of crown shedding and streamlining on the survival of loblolly pine exposed to acute wind. Canadian Journal of Forest Research 25:704-712.

King, D.A. 1986. Tree form: Height growth, and susceptibility to wind damage in Acer saccharum. Ecology 67:980-990.

King, D.A., and O.L. Loucks. 1978. The theory of tree bole and branch form. Radiation and Environmental Biophysics 15:141-165.

Landsberg, J.J., and G.B. James. 1971. Wind profiles in plant canopies: Studies on an analytical model. Journal of Applied Ecology 8(2):729-741. [tom: Landsberg and James 1971 not cited in article]

Lilly, S.J. 2001. Arborists' Certification Study Guide. International Society of Arboriculture. Champaign IL. 222 pp.

Marini, R.P. 1999. Are nonsignificant differences really not significant? HortScience 34(5):761-762.

Matheny, N.P., and J.R. Clark. 1994. A Photographic Guide to the Evaluation of Hazard Trees in Urban Areas (2nd ed.). International Society of Arboriculture. Champaign, IL. 85 pp.

Mayhead, G.J. 1973. Some drag coefficients for British trees derived from wind tunnel studies. Agricultural Meteorology 12:123-130.

Mayhead, G.J., J.B.H. Gardiner, and D.W. Durrant. 1975. A Report on the Physical Properties of Conifers in Relation to Plantation Stability. Forestry Commission Research and Development Division, Roslin, Midlothian, UK. 39 pp.

Moore, J.R., and D.A. Maguire. 2001. The mechanics of trees under wind loading. In Smiley, E.T., and K.D. Coder (Eds.). Tree Structure and Mechanics Conference Proceedings: How Trees Stand Up and Fall Down. International Society of Arboriculture, Champaign, IL. 184 pp. 
Niklas, K.J., and H.-C. Spatz. 2000. Wind-induced stresses in cherry trees: Evidence against the hypothesis of constant stress levels. Trees 14:230-237.

Petty, J.S., and C. Swain. 1985. Factors influencing stem breakage of conifers in high winds. Forestry 58(1):75-84.

Petty, J.A., and R. Worrell. 1981. Stability of coniferous tree stems in relation to damage by snow. Forestry 54:115128.

Putz, F.E., P.D. Coley, K. Lu, A. Montalvo, and A. Aiello. 1983. Uprooting and snapping of trees: Structural determinants and ecological consequences. Canadian Journal of Forest Research 13(5):1011-1020.

Roodbaracky, H.J., C.J. Baker, A.R. Dawson, and C.J. Wright. 1994. Experimental observations of the aerodynamic characteristics of urban trees. Journal of Wind Engineering and Industrial Aerodynamics 52:171184.

Rowan, C.A., S.J. Mitchell, and H. Temesgen. 2003. Effectiveness of clearcut edge windfirming treatments in coastal British Columbia: Short-term results. Forestry 76(1):55-65.

Rudnicki, M., Mitchell, S.J., and Novak, M.D. 2004. Wind tunnel measurements of crown streamlining and drag relationships for three conifer species. Canadian Journal of Forest Research. 34:666-676.

Shigo, A.L. 1986. A New Tree Biology. Shigo and Trees, Associates, Durham, NH. 132 pp.

Vogel, S. 1989. Drag and reconfiguration of broad leaves in high wind. Journal of Experimental Botany 78(4):941948.

_ 1994. Life in Moving Fluids (2nd ed.). Princeton University Press, Princeton, NJ. 467 pp.

Vollsinger, S., Mitchell, S.J., Byrne, K.E., Novak, M.D., and Rudnicki, M. Wind tunnel measurements of crown streamlining and drag relationships for several hardwood species. Canadian Journal of Forest Research 35:1238-1249.
Acknowledgments. Thanks to Elden LeBrun and Ethan Stewart of the Bartlett Tree Research Laboratory for conducting the field portion of this work; Neil Clark (USDA Forest Service) and John Peterson (Virginia Tech Forestry Department) for analyzing digital images; and Dr. Bruce R. Fraedrich, Thomas Martin (Bartlett Tree Research Laboratory), Dr. Roger Harris, and Dr. Susan Day (Virginia Tech) for reviewing and commenting on this paper.

E. Thomas Smiley, Ph.D. (corresponding author)

Arboriculture Researcher

Bartlett Tree Research Laboratory

13768 Hamilton Road

Charlotte, NC, 28278, U.S.

Brian Kane, Ph.D.

MAA Assistant Professor of Commercial Arboriculture University of Massachusetts at Amherst

Amherst, MA, 01003, U.S. 
Résumé. La force exercée par le vent, le moment de flexion, la hauteur et la masse ont été évalués pour 81 érables rouges (Acer rubrum) avant et après leur élagage. Les arbres ont été éclaircis, écimés ou élagués en queue de lion. Les trois interventions d'élagage ont diminué significativement la force exercée par le vent comparativement aux arbres non élagués, et ce à tous les tests de vélocité du vent $(11,16$ et $20 \mathrm{~m} / \mathrm{sec}$.). La réduction de la force exercée par le vent s'est accrue avec l'augmentation de la vélocité du vent. Les différences de réduction de la force exercée par le vent n'étaient pas significatives entre l'écimage et l'éclaircissage, et ce quelle que soit la vélocité du vent. La diminution de la force exercée par le vent était reliée de manière linéaire à la masse enlevée lors de l'élagage. Comparativement aux même arbres avant que l'élagage ne soit effectué, le centre de force en hauteur était rabaissé de manière significative chez les arbres écimés ou éclaircis, alors qu'il n'était nullement modifié dans le de ceux élagués en queue de lion.

Zusammenfassung. Bei 81 Rotahornen (Acer rubrum) wurde die Windlast, das Biegemoment, Höhe und Gewicht vor und nach einer Schnittmaßnahme bestimmt. Die Bäume wurden ausgedünnt, reduziert, getrimmt oder der Blätter entledigt. Alle drei Rückschnittmethoden reduzierten die Windlast im Vergleich zu nicht geschnittenen Bäumen bei alle drei getesteten Windstärken. Die Reduzierung der Windlast stieg mit wachsender
Geschwindigkeit. Die Unterschiede in der Windlastreduktion zwischen rückgeschnittenen und ausgedünnten Bäumen waren bei keiner Windstärke besonders groß. Die Reduktion der Windlast stand linear zu der Gewichtsmenge bei den Rückschnittmaßnahmen. Verglichen mit den gleichen Bäumen vor dem Schnitt lag das Zentrum der Drucklast duetlich tiefer bei gedünnten und reduzierten Bäumen, während es sich bei getrimmten Bäumen nicht veränderte.

Resumen. La altura, el peso y la carga del viento fueron determinados en ochenta y un maples rojos (Acer rubrum) antes y después de su poda. Los árboles fueron aclarados, reducidos, cortados en forma de "cola de león" o desprovistos de follaje. Todos los tratamientos de poda en árboles redujeron la presión del viento significativamente, comparados con los árboles sin podar en todas las velocidades probadas $\left[11,16,20 \mathrm{~m}^{*} \mathrm{~s}^{-1}(25,35 \mathrm{y} 45 \mathrm{mph})\right]$. La reducción de la presión del viento aumentó cuando incrementó la velocidad. Las diferencias en la reducción de la presión del viento entre las podas de reducción y el aclareo no fueron significativas a ninguna velocidad. La reducción de la presión del viento estuvo linealmente relacionada con la cantidad de peso removido con los tratamientos de poda. Comparado con los mismos árboles antes de la poda, el centro de la carga de presión se redujo significativamente en los árboles aclarados y reducidos, mientras que el centro de la carga de presión no cambió en los árboles cortados en forma de "cola de león". 